\title{
Stability Analysis in Mungbean (Vigna radiata L.) for Micronutrients (Fe \& Zn) and Seed Yield
}

\author{
Renu Singh ${ }^{1 *}$, Adriaan W. Van Heusden ${ }^{2}$, Suman Bala ${ }^{1}$, \\ Kanisht Batra ${ }^{3}$ and Richard G.F. Visser ${ }^{2}$
}

${ }^{1}$ Centre for Plant Biotechnology, Hisar, Haryana - 125004, India

${ }^{2}$ Plant Research International (PRI), Wageningen University and Research, The Netherlands

${ }^{3}$ National Fellow Laboratory, National Research Centre on Equines (NRCE), Hisar, India

*Corresponding author

\section{A B S T R A C T}

\begin{tabular}{|l|}
\hline K e y w o r d s \\
Interaction, Iron, \\
$\begin{array}{l}\text { Mungbean, Seed, } \\
\text { Stability analysis, } \\
\text { Zinc }\end{array}$ \\
\hline Article Info \\
\hline $\begin{array}{l}\text { Accepted: } \\
\text { 04 March } 2018 \\
\text { Available Online: } \\
\text { 10 April 2018 }\end{array}$ \\
\hline
\end{tabular}

Keywords

\section{Introduction}

Mungbean [Vigna radiata (L.) Wilczek], $2 \mathrm{n}=22$ is an important wide spreading herbaceous, annual, self-pollinated legume pulse crop in India and occupies third important pulse crop after Pigeonpea and Chickpea. It is grown throughout Asia, Australia, West Indies, South and North America, Tropical and Subtropical Africa of which, India is the largest producer and consumer of mungbean accounting for about 65 per cent of the world's acreage and 54 per cent of the world's production (Singh and Singh, 2011). It is rich in quality proteins, minerals and vitamin; often preferred to other pulses due to its better digestibility and less flatulence problem owing to lower content of raffinose, stachyose and verbascose. In India pulses are cultivated throughout the year and India is the world's largest producer and consumer of pulses occupying an area of 8.32 million hectare with a total production of 0.87 million tonnes during kharif season and 0.64 million tonnes in rabi season 2014-15 and thus having productivity of $912 \mathrm{~kg} / \mathrm{ha}$ 
(Anonymous, 2015). Genetic diversity and variability plays an important role in a successful molecular breeding programme and genetic variability is essential to meet the diversified goals of plant molecular breeding.

Genetic improvement of crop is largely depending on the magnitude of genetic variability and the extent to which desirable traits are heritable. The environment is changing day by day and there is urgent need to evaluate their performance for more site specific managements. Genotypes behave differently to both soil and environmental factors. The genotype-environment interaction is challenging issue for molecular breeders and plays major role in developing improved stable varieties for dietary improvement. The phenotypic and genotypic coefficient of cultivars and searching for superior genotypes.

Cultivars of mungbean show variability for yield, seed protein along with iron and zinc concentrations. Now there is a need to develop genotypes that can withstand unpredictable transient environmental fluctuation. It therefore, makes sense to develop a micronutrient breeding programme for mungbean. Hence the major objective behind this experiment is to select stable genotypes for nutritional quality and seed yield.

\section{Materials and Methods}

The experimental material comprised of thirty elite genotypes developed by different research institutes. These varieties were grown in six different environments; E1 (Control), E2 (Recommended Dose of Fertilizer (RDF) + $0.5 \% \mathrm{FeSO}_{4}$ foliar spray), E3 (RDF + SSP (Single Super Phosphate, $\left.\mathrm{Ca}\left(\mathrm{H}_{2} \mathrm{OP}_{4}\right) 2 . \mathrm{H}_{2} \mathrm{O}\right)=$ contains $16 \%$ water soluble $\mathrm{P}_{2} \mathrm{O}_{5}, 12 \%$ sulphur \& $21 \%$ calcium)), E4 (RDF + SSP + $0.5 \% \mathrm{FeSO}_{4}$ foliar spray), $\mathrm{E} 5$ ( $\mathrm{RDF}+\mathrm{SSP}+$ $25 \mathrm{~kg} / \mathrm{ha} \mathrm{ZnSO}_{4}$ (direct to soil)) and E6 (RDF + $\mathrm{SSP}+\mathrm{ZnSO}_{4}+0.5 \% \mathrm{FeSO}_{4}$ foliar spray) in a randomized complete block design during kharif 2010 with 3 replications per environment at CCS HAU research farm, Hisar. Each plot consisted of two rows of $4 \mathrm{~m}$ length with spacing $30 \mathrm{~cm}$ between rows and $10 \mathrm{~cm}$ between plants. Recommended cultural practices were followed to grow healthy crop. Five randomly selected plants from each genotype were tagged for data collection on seed yield/plant $(\mathrm{g})$, protein content $(\%)$, iron content $(\mathrm{mg} / 100 \mathrm{~g}$ dry weight seed) and zinc content (mg/100 g dry weight of seed).

The mean values were used for analysis of variance using OPStat software. The effects of genotype, environment and genotype $\mathrm{x}$ environment interactions were estimated following the method described by Eberhart and Russell (1966). Atomic Absorption Spectrophotometer (AAS) analysis was implemented for both iron and zinc concentration according to the technique of Benton -Jones (1989) and was also based on nitric/perchloric acid digestion with sample read on 2380, Perkin Elmer (USA) at Central Laboratory, CCS HAU, Hisar. Readings were evaluated against standard curves prepared from iron diluted to a concentration of 100 $\mathrm{mg} / \mathrm{l}$ and zinc diluted to $50 \mathrm{mg} / \mathrm{l}$.

\section{Results and Discussion}

Pooled analysis of variance showed highly significant differences among the genotypes and environments for yield, iron and zinc content (Table 1), indicating the presence of genetic variability among the genotypes as well as the environments under study. The genotype - environment (GxE) interaction was further partitioned into linear and nonlinear (pooled deviation) components. The GxE (linear) interaction was highly significant when tested against pooled deviation, which revealed that there are genetic differences among genotypes for their regression on the environment index. 
Table.1 Analysis of variance for yield, iron $(\mathrm{Fe})$ and zinc $(\mathrm{Zn})$ in mungbean under six different environmental conditions

\begin{tabular}{|l|c|c|c|c|}
\hline Source of variation & d.f. & SYP & Fe & Zn \\
\hline Genotypes (G) & 29 & $79.3^{* *++}$ & $14.7^{* *++}$ & $3.1^{* * *}$ \\
\hline Environment (E) & 5 & $54.1^{* *+}$ & $129.7^{* *++}$ & $15.2^{* *++}$ \\
\hline G x E & 145 & $19.9^{* *}$ & $10.8^{* *++}$ & $3.1^{* *}$ \\
\hline Environments + (G x E) & 150 & $21.1^{* *}$ & $14.8^{* *+}$ & $3.4^{* *}$ \\
\hline E (linear) & 1 & $270.2^{* *++}$ & $648.5^{* *++}$ & $76.1^{* *++}$ \\
\hline G (linear) x E & 29 & $24.7^{* *}$ & $25.9^{* *++}$ & $4.2^{* *+}$ \\
\hline Pooled deviation & 120 & $18.1^{* *}$ & $6.9^{* *}$ & $2.7^{* *}$ \\
\hline Pooled error & 348 & 1.5 & 2.6 & 0.1 \\
\hline
\end{tabular}

$*, * *=$ Significant mean square against pooled error at $5 \%$ and $1 \%$ probability level respectively

,$+++=$ Significant mean square against pooled deviation at $5 \%$ and $1 \%$ probability level respectively

Table.2 Estimates of stability parameters for seed yield, iron and zinc content in mungbean

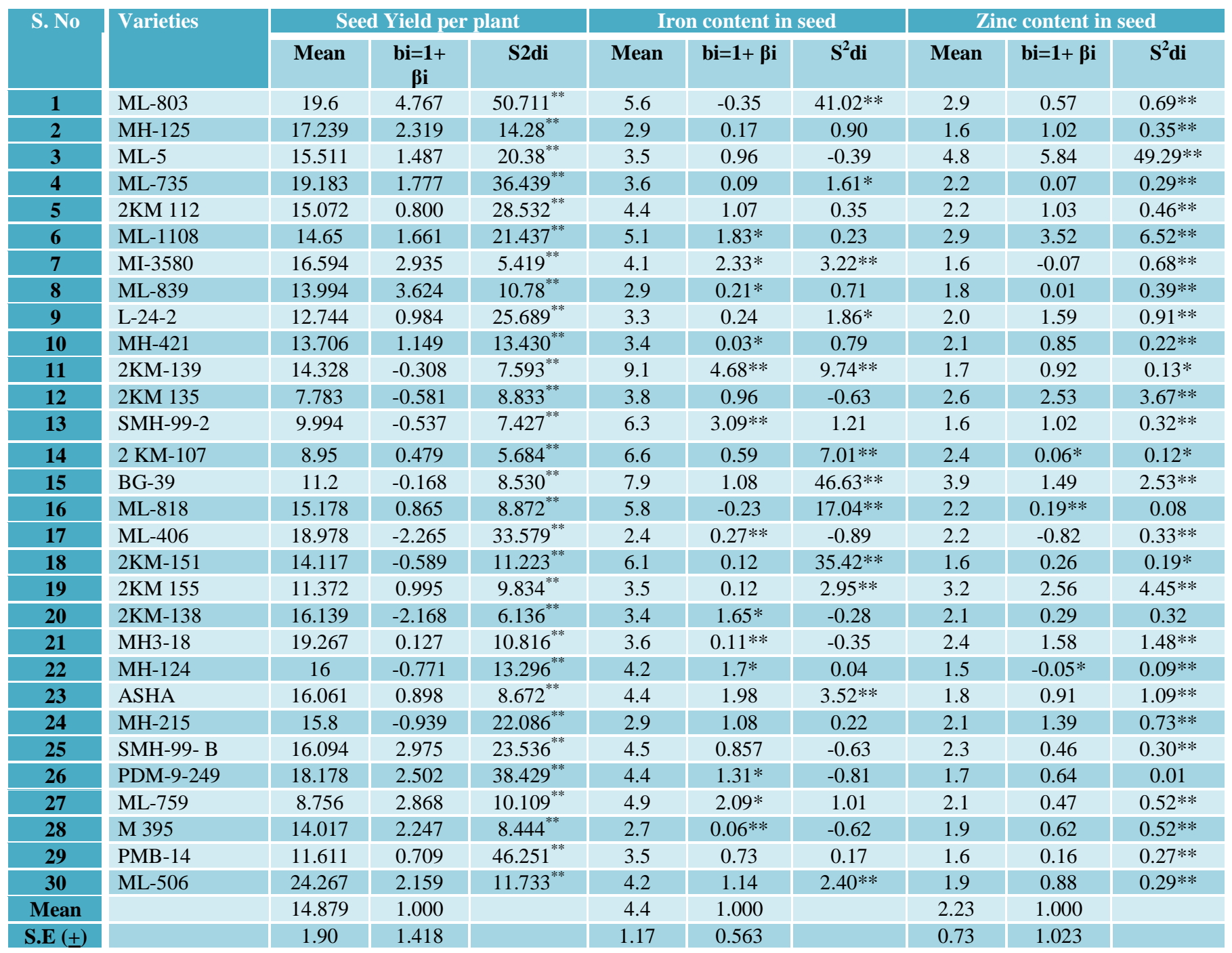

*Significant at $\mathrm{P}=0.05$ 
Table.3 Grouping of stable genotypes for iron and zinc content on basis of the three stability parameters

\begin{tabular}{|c|c|c|c|}
\hline & $\begin{array}{l}\text { Iron content in seeds of } \\
\text { mungbean }\end{array}$ & $\begin{array}{l}\text { Zinc content in seeds of } \\
\text { mungbean }\end{array}$ & $\begin{array}{l}\text { Environment } \\
\text { conditions }\end{array}$ \\
\hline $\begin{array}{l}\mathrm{Xi} \geq \mathrm{X} \\
\text { bi }>1.0 \\
\mathbf{S}^{2} \mathbf{d i}=+\end{array}$ & $\begin{array}{l}\text { ML-1108, SMH-99-2, 2KM-138*, } \\
\text { MH-124*, PDM-9-249,ML-759 (6, } \\
\left.13,20^{*}, 22^{*}, 26,27\right)\end{array}$ & - & $\begin{array}{l}\text { Good for favourable } \\
\text { environment conditions }\end{array}$ \\
\hline $\begin{array}{l}\mathrm{Xi} \geq \mathrm{X} \\
\mathbf{b i}=1.0 \\
\mathbf{S}^{2} \mathbf{d i}=+\end{array}$ & $\begin{array}{l}\text { ML-5*, 2KM-112, 2KM-135*, MH- } \\
215^{*}, \text { SMH-99-B }(3 *, 5,12 * 24 * 25)\end{array}$ & - & $\begin{array}{l}\text { Good for all type of } \\
\text { environments }\end{array}$ \\
\hline $\begin{array}{l}\mathrm{Xi} \geq \mathrm{X} \\
\text { bi }<1.0 \\
\mathrm{~S}^{2} \mathrm{di}=+\end{array}$ & $\begin{array}{l}\text { MH-125*, ML-839*, MH-421*, ML- } \\
406 *, \mathrm{MH}-318^{*}, \mathrm{M}-395^{*}, \mathrm{PMB}-14 * \\
\left(2 * 8 * 10^{*} 17 * 21 * 28^{*} 29 *\right)\end{array}$ & ML-818 (16) & $\begin{array}{l}\text { Good for poor } \\
\text { environments }\end{array}$ \\
\hline
\end{tabular}

$+=$ non-significant; $*=\mathrm{Xi}<\mathrm{X} ; \mathrm{X}=$ average mean; bi= regression coefficient; ${ }^{-} \mathrm{S}^{2} \mathrm{di}=$ mean square deviation from the regression

The GxE (linear) was significant for seed yield, iron content and zinc content, indicating that stability of genotypes could be judged on the basis of relative magnitude of variance. The genotypes had unpredictable performance over the environment for zinc content. The observed high magnitude of environmental (linear) effect in comparison to GxE (linear) for all the characters investigated suggested that high magnitude of environmental (linear) effect might be responsible for high adaptation of these genotypes in relation to nutritional quality and yield.

An ideal variety is characterized by high or desirable mean coupled with linear regression coefficient (b) equal or close to unity and mean square deviations $\left(S^{2} \mathrm{di}\right)$ equal or close to zero (non-significant). The estimates of stability parameters of individual genotypes (bi and $S^{2}$ di) suggested that none had the predictable performance for all the characters investigated (Table 2). The simultaneous consideration of three parameters of stability (Table 2) for the individual genotype revealed that highest seed yield per plant over the grand mean yield was observed for sixteen genotypes out of thirty genotypes showing highly significant deviation from regression. Due to high values of $\mathrm{S}^{2} \mathrm{di}$, these genotypes are expected to give good seed yield under favourable environmental conditions (Kamnavar et al., 2011).

The genotypes ML-506, MH 3-18, PDM-9249 and ML-406 were high yielder (Between 18.97-24.26g). They had high $\mathrm{S}^{2} \mathrm{di}$ showing sensitivity to environmental changes. These varieties gave higher seed yield when the environmental conditions were conducive.

The better performance of the genotypes for iron content $(\mathrm{mg} / 100 \mathrm{~g}$ dry weight of seed) was shown by $2 \mathrm{KM}-139$ (9.1mg) followed by BG-39 (7.9 mg) and 2KM-107 (6.6mg) over the grand mean with regression values 4.68, 1.08 and 0.59 respectively. All these varieties had high deviation from regression indicating sensitivity to environmental changes.

Similarly, for the zinc content genotypes; ML-5, BG-39 and 2KM-155 with regression values 5.84, 1.49 and 2.56 respectively. And highly significant deviations from regression, these genotypes are expected to have higher zinc content under favourable environmental conditions perusing high values of $S^{2} \mathrm{di}$ (Susan-Nichimbi and George, 2010).

The deviation from regression for majority of the genotypes was highly significant that 
revealed the response of these genotypes was unpredictable and that they were more suitable for sites with better environment. Genotypes presented in table 3 with better performance for seed yield, iron and zinc content, may be recommended for better environment and could be potentially utilized for developing seed micronutrients enriched mungbean cultivars.

\section{References}

Anonymous, 2015. Directorate of Economics and Statistics, Department of Agriculture, Cooperation and Farmers welfare. Ministry of Agriculture and Farmers welfare, Government of India, New Delhi.

Benton -Jones, J. 1989. Plant analysis techniques. Benton-Jones Laboratories, Georgia.
Eberhart, S.A. and Russell, W.A. 1966. Stability parameters for comparing varieties. Crop Science. 6(1): 36-40.

Kamnavar, P.Y., A.G. Vijaykumar, S.B. Ravanappa, M. Ganajaxi, Arunkumar, P.H Kuchanur and Salimath, P.M. 2011. Genotype x Environment interaction in Mungbean [Vigna radiata (L.) Wilczek] cultivars grown in different agroclimatic zones of Karnataka. Electronic J. of Plant Br., 2(4): 501-506.

Singh, D.P. and Singh, B.B. 2011. Breeding for tolerance to abiotic stresses in mungbean. J. Food Leg., 24(2): 83-90.

Susan-Nichimbi, M. and George, M.T. 2010. The effects of the environment on iron and zinc concentrations and performance of Common Bean (Phaseoulus vulgris L.) genotypes. Asian J. Plant Sci. 9(8): 455-463.

\section{How to cite this article:}

Renu Singh, Adriaan W. Van Heusden, Suman Bala, Kanisht Batra and Richard G.F. Visser. 2018. Stability Analysis in Mungbean (Vigna radiata L.) for Micronutrients (Fe \& Zn) and Seed Yield. Int.J.Curr.Microbiol.App.Sci. 7(04): 419-423.

doi: https://doi.org/10.20546/ijcmas.2018.704.048 